\title{
Prevalence of human herpesvirus 6 in lung tissue from children with pneumonitis
}

\author{
J A Hammerling, R S Lambrecht, K S Kehl, D R Carrigan
}

\begin{abstract}
Aims/background-Human herpesvirus type $6(\mathrm{HHV}-6)$ is the aetiological agent of exanthem subitum, and has also been linked with a variety of other diseases. The aim of this study was to investigate the role of HHV-6 in pneumonitis in children. Methods-Formalin fixed, paraffin wax embedded lung tissue from 33 children (age range two months to 16 years) who died with pneumonitis was subjected to immunohistochemical staining for HHV-6 using an avidin-biotin method.

Results-Active HHV-6 infection was demonstrated in four children: a bone marrow transplant recipient with concomitant adenovirus infection, a patient with hepatitis of unknown aetiology, a patient with congenital anomalies, and a patient with congenital immunodeficiency.

Conclusion-Accurate localisation of HHV-6 is possible in postmortem lung tissue. HHV-6 either alone or in combination with other pathogens may play a role in the development of pneumonitis.

(F Clin Pathol 1996;49:802-804)
\end{abstract}

Keywords: human herpesvirus 6, viral pneumonitis, children.

Human herpesvirus 6 (HHV-6) is a recently discovered virus that, on the basis of serological evidence, seems to infect most children by the age of three years. ${ }^{1}$ However, the clinical manifestations of primary HHV-6 infection and reactivation have not been well defined, except for the report by Yamanishi et $a l^{2}$ that identified HHV-6 as the agent of exanthem subitum and a report by Hall et $a l^{3}$ on complications and reactivation of HHV- 6 in children. Previous work from Carrigan et al ${ }^{45}$ has established HHV-6 as a cause of interstitial pneumonitis in bone marrow transplant recipients and patients with AIDS.

Very few data exist regarding the role of

Department of Pathology, Children's Hospital of Wisconsin, Milwaukee, Wisconsin, USA

Correspondence to: Julie A Hammerling, Department of Pathology, Children's Hospital of Wisconsin, $9000 \mathrm{~W}$. Wisconsin Ave, Milwaukee, WI 53201, USA.

Accepted for publication 27 June 1996 were retreived from the archives of the Department of Pathology, Children's Hospital of Wisconsin. All patients had died between 1991 and 1994.

Cases of both diagnosed and idiopathic pneumonitis were included. Cases were also subdivided according to age: less than two years for presumed primary infections and more than two years for presumed late primary or reactivation disease. One of the cases studied (case 4; tables 2 and 3 ) has been described in detail previously, ${ }^{6}$ but was independently selected by the criteria used here.

DETECTION OF HHV-6

Immunohistochemical staining for the identification of HHV-6 infected cells based on an avidin-biotin system (Vector Laboratories, Burlingame, California, USA) has been described in detail by Russler et al. ${ }^{7}$ The primary antibody used was a rabbit hyperimmune serum specific for cells actively infected with HHV-6. The alkaline phosphatase enzyme was used with a Vector Red reaction substrate and haematoxylin counterstain.

A negative control of each section was run in parallel with pre-immune serum from the same rabbit used for production of the HHV- 6 specific antiserum. A positive control consisted of lung tissue from a young male bone marrow transplant recipient who died of fulminant HHV-6 pneumonitis. ${ }^{4}$ Internal controls of normal lung tissue, cytomegalovirus (CMV) infected lung tissue and adenovirus infected lung tissue, from patients who had these viruses isolated from necropsy lung tissue, were used as negative controls and proof against crossreactivity of the antibody. Lack of crossreactivity of the rabbit antiserum has also been shown previously. ${ }^{6}$

HHV-6 infected cells were counted and the number of infected cells per $\mathrm{cm}^{2}$ was calculated. Measurement of the size of the tissue sections in $\mathrm{cm}^{2}$ excluded regions that were acellular or necrotic.

Determination of HHV-6 infected cell types was accomplished by double immunohistochemical staining, which has been described previously. ${ }^{8}$ Briefly, the rabbit antiserum was used first with an alkaline phosphatase/Vector Red substrate (fig 1). Then, cell type specific monoclonal antibodies were used with a horseradish peroxidase/Vector SG substrate. The cell type specific primary antibodies used were: mouse anti-human macrophage (CD68); mouse anti-human epithelial membrane antigen (EMA); and mouse anti-human $\mathrm{T}$ cell

\section{Methods}

An average of eight paraffin wax blocks of lung tissue prepared at necropsy from each of 33 paediatric patients with any type of pneumonitis as a primary or contributing cause of death 


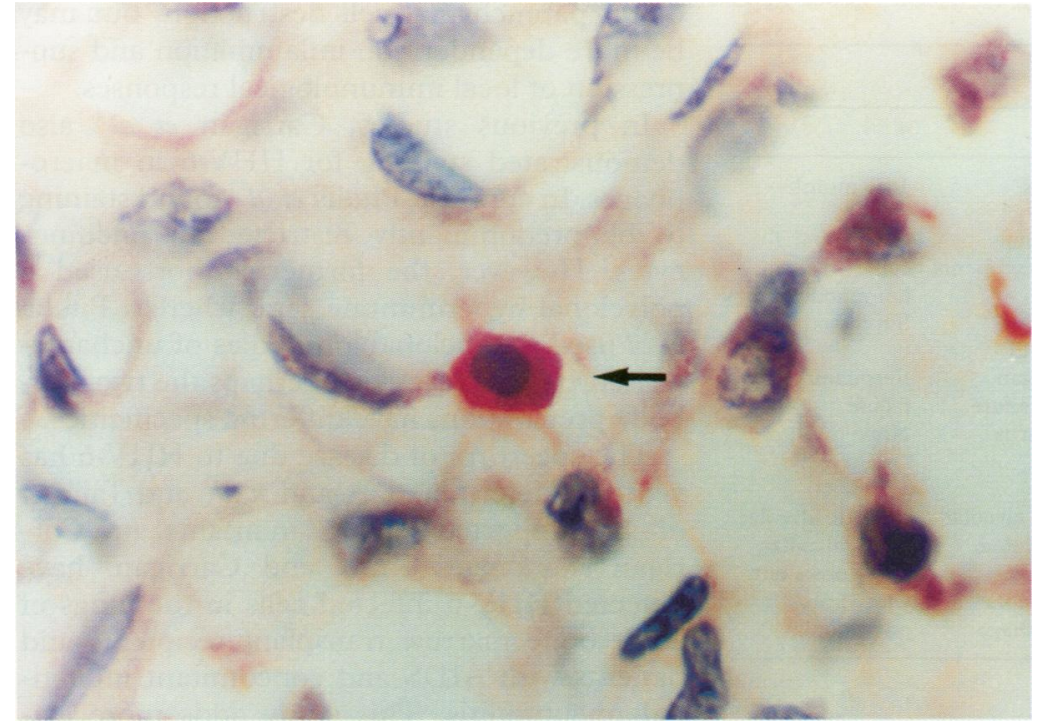

Figure 1 Section of a patient's lung after immunohistochemical staining with a rabbit hyperimmune serum specific for $\mathrm{HHV}$-6 infected cells. Arrow indicates virus antigen positive cell. (Vector Red reaction substrate with haematoxylin counterstain; original magnification $\times 400$.) phages, on the basis of their reactivity with the appropriate monoclonal antibody. The numbers of lymphocytes and macrophages infected were roughly equal, with no epithelial cell involvement detected.

The cause of death in two of the four patients infected with HHV-6 was identified as respiratory failure in cases 1 and 4, as hepatic necrosis in case 2 , and as systemic adenovirus infection in case 3 .

Two of the four patients with $\mathrm{HHV}-6$ infection were known to be immunocompromised, either because of bone marrow transplantation or congenital immune deficiency. The clinical features of the patients are presented in table 3. Potential pathogens identified at the time of death are listed in table 4.

\section{Discussion}

This study demonstrates that some cases of idiopathic interstitial pneumonitis are probably caused by active HHV- 6 infection. Comparing the rate of positive HHV-6 cases $(n=4)$ with those of CMV ( $n=4)$, currently one of the most common causes of interstitial pneumonitis in the immunocompromised patient, we found equal rates of positivity (table 4 ).

Two of the four patients infected with HHV-6 were known to be immunocompromised. The remaining "competent" patients had no known immunodeficiencies, but could have been functionally compromised by nutritional status or other factors. Although data are limited, this study suggests that HHV-6 infection has no preference for host immune state in the paediatric patient. The otherwise healthy child can acquire serious and fatal primary infection (for example, case 2) as readily as the immunocompromised patient.

Three of the four patients with HHV-6 infection were less than two years old, suggesting primary infections. One case in a three and a half year old child is suggestive of reactivation disease. However, no serologies were available on any of the patients studied, preventing determination of HHV- 6 immune status. The three children with primary infections also had high levels of HHV-6 infected cells $/ \mathrm{cm}^{2}$. One apparently immunocompetent child (case 2), most likely developed severe HHV-6 pneumonitis and hepatitis. As HHV-6 was identified in the lung, it can be speculated that the liver dysfunction in this patient was also the result of a HHV-6 infection. ${ }^{9}{ }^{10}$ A severe primary HHV-6 infection was also present in case 4 . However, in this case it is hypothesised that congenital HHV-6 infection resulted in immunodeficiency with eventual HHV-6 pneumonitis. This case has been described in detail previously. ${ }^{6}$ Case 1 was also an apparently immunocompetent child with severe primary HHV-6 infection. Staphylococcus aureus pneumonia was diagnosed at necropsy. The $S$ aureus infection may have been secondary to the HHV-6 infection, as HHV-6 infection can severely compromise the function of phagocytic leucocytes. ${ }^{11}$

In the three and a half year old child with a low level of HHV-6 infection (29 HHV-6 infected cells per $\mathrm{cm}^{2}$ of tissue) HHV-6 infection probably reactivated as a result of

\begin{tabular}{ll}
\hline Case number & HHV-6 infected cells $/ \mathrm{cm}^{2}$ \\
\hline 1 & 542 \\
2 & 263 \\
3 & 29 \\
4 & 579 \\
All others & 0 \\
\end{tabular}


Table 3 Clinical features

\begin{tabular}{|c|c|c|c|c|}
\hline & \multicolumn{4}{|l|}{ Case number } \\
\hline & 1 & 2 & 3 & 4 \\
\hline Age & 2 years & 18 months & $31 / 2$ years & $14 \frac{1}{2}$ months \\
\hline Sex & $\mathrm{F}$ & $\mathbf{M}$ & $M$ & $\mathbf{F}$ \\
\hline $\begin{array}{l}\text { Underlying } \\
\text { condition }\end{array}$ & $\begin{array}{l}\text { Congenital } \\
\text { anomalies }\end{array}$ & None & $\begin{array}{l}\text { Congenital } \\
\text { granulocytopenia }\end{array}$ & $\begin{array}{l}\text { Congenital } \mathrm{T} \\
\text { cell } \\
\text { immunodeficiency }\end{array}$ \\
\hline Immune status & Competent & Competent & $\begin{array}{l}\text { Suppressed } \\
\text { post-BMT }\end{array}$ & Supressed \\
\hline Cause of death & Respiratory failure & $\begin{array}{l}\text { Hepatic and } \\
\text { respiratory failure }\end{array}$ & $\begin{array}{l}\text { Multiorgan } \\
\text { system failure }\end{array}$ & $\begin{array}{l}\text { Respiratory } \\
\text { failure }\end{array}$ \\
\hline $\begin{array}{l}\text { Pathogens } \\
\text { identified at } \\
\text { necropsy }\end{array}$ & $\begin{array}{l}\text { Staphylococcus } \\
\text { aureus }\end{array}$ & None & Adenovirus & None \\
\hline $\begin{array}{c}\text { Histological } \\
\text { diagnosis }\end{array}$ & $\begin{array}{l}\text { Bronchopneumonia; } \\
\text { hyaline } \\
\text { membranes }\end{array}$ & $\begin{array}{l}\text { Bronchopneumonia; } \\
\text { hyaline } \\
\text { membranes; focal } \\
\text { haemorrhage }\end{array}$ & $\begin{array}{l}\text { Fibrotic alveolar } \\
\text { septa; hyaline } \\
\text { membranes; } \\
\text { intra-alveolar } \\
\text { haemorrhage }\end{array}$ & $\begin{array}{l}\text { Fibrotic alveolar } \\
\text { septa; alveolar } \\
\text { cells consistent } \\
\text { with viral } \\
\text { pneumonia }\end{array}$ \\
\hline
\end{tabular}

$\mathrm{BMT}=$ bone marrow transplantation.

Table 4 Potential pathogens detected

\begin{tabular}{lll}
\hline Potential pathogen & $\begin{array}{l}\text { Number of } \\
\text { patients }\end{array}$ & $\begin{array}{l}\text { Number of patients } \\
\text { with HHV-6 }\end{array}$ \\
\hline No organism & 22 & 2 \\
CMV & 4 & 0 \\
Adenovirus & 2 & 1 \\
Parainfluenza virus & 1 & 0 \\
$\begin{array}{l}\text { Aspergillus } \\
\text { Staphylococcus } \\
\quad \text { aureus }\end{array}$ & 1 & 0 \\
$\begin{array}{l}\text { Streptococcus } \\
\text { pneumoniae }\end{array}$ & 1 & 1 \\
$\begin{array}{c}\text { Pseudomonas } \\
\text { aeruginosa }\end{array}$ & 1 & 0 \\
Total & 33 & 0 \\
\hline
\end{tabular}

immunosuppression following bone marrow transplantation. The patient was diagnosed at necropsy with systemic adenovirus. Whether a synergism exists between HHV-6 and adenovirus, such as that observed between HHV- 6 and HIV, ${ }^{12}{ }^{13}$ is uncertain. Coinfection with two viruses is common in bone marrow transplant recipients.

The four patients infected with HHV-6 had varying numbers of virus infected cells. HHV- 6 infected cells were not found in the remaining patients. These numbers reflect the amount of active HHV-6 infection in the lung tissue at the time of necropsy. Based on the report by Knox, ${ }^{14}$ the two values in the 500 range most likely relate to clinically significant levels of infection, and are probably the primary cause of fatal pneumonitis in cases 1 and 4. The presence of only 29 infected cells $/ \mathrm{cm}^{2}$ in case 3 almost certainly reflects a subclinical level of infection in a patient with a severe adenoviral infection.

The identification of HHV-6 infected cell types as lymphocytes and macrophages suggests that the pathogenic mechanism of HHV-6 pneumonitis is probably not caused by direct parenchymal cell destruction, but may be more dependent on inflammation and suppression of local immunological responses.

In previous studies, Carrigan et $\mathrm{al}^{4}$ also demonstrated staining for HHV- 6 in macrophages. In contrast, Pitalia $e t a l^{15}$ found staining to be predominantly restricted to pneumocytes. However, the former authors used a polyclonal hyperimmune sera, whereas Pitalia et al used monoclonal antibodies of uncharacterised epitope reactivity. Perhaps the two antibody preparations have differing specificities.

The spectrum of disease due to HHV- 6 has yet to be determined. Asano $e t a l^{9}$ and Tajiri et $a l^{10}$ have reported hepatitis in infants, and Carrigan et $a l^{4}$ and Knox and Carrigan ${ }^{5}$ have detected HHV-6 infected cells in the lungs of adult bone marrow transplant recipients and patients with AIDS and concomitant interstitial pneumonitis. This study adds more evidence to the role HHV-6 plays, specifically in disease of paediatric patients.

Until easier ways of detecting HHV-6 become available, and testing is not restricted to research laboratories, the prevalence of disease will be underestimated.

1 Pellett PE, Black JB, Yamamoto M. Human herpesvirus 6 : the virus and the research for its role as a human pathogen. Adv Virus Res 1992;41:1-52.

2 Yamanishi $\mathrm{K}$, Okono $\mathrm{T}$, Shiraki $\mathrm{K}$, Takahashi $\mathrm{M}$, Kondo $\mathrm{T}$ Asano $\mathrm{Y}$, et al. Identification of human herpesvirus-6 as a causal agent for exanthem subitum. Lancet 1988;i:1065-7.

3 Hall CB, Long CE, Schnabel KC, Caserta MT, McIntyre $\mathrm{KM}$, Costanzo MA, et al. Human herpes virus- 6 infection in children. N Engl f Med 1994;331:432-8.

4 Carrigan DR, Drobyski WR, Russler SK, Tapper MA, Knox $\mathrm{KK}$, Ash RC. Interstitial pneumonitis associated with human herpesvirus- 6 infection after marrow transplantation. Lancet 1991;338:147-9.

5 Knox KK, Carrigan DR. Disseminated active HHV-6 infec tions in patients with AIDS. Lancet 1994;343:577-8.

6 Knox KK, Pietryga D, Harrington DJ, Franciosi R Carrigan DR. Progressive immunodeficiency and fatal pneumonitis associated with human herpesvirus 6 infection in an infant. Clin Infect Dis 1995;20:406-13.

7 Russler SK, Tapper MA, Knox KK, Liepins A, Carrigan DR. Pneumonitis associated with coinfection by human herpesvirus-6 and legionella in an immunocompeten adult. Am f Pathol 1991;138: 1405-11.

8 Toorkey CB, Carrigan DR. Immunohistochemical detection of an immediate early antigen of human cytomegalovirus in normal tissues. $\mathcal{F}$ Infect Dis 1989;160:741-51.

9 Asano Y, Hoshikawa T, Suga S, Yazaki T, Kondo K, Yamanishi K. Fatal fulminant hepatitis in an infant with human herpesvirus-6 infection. Lancet 1990;335:863.

10 Tajiri H, Nose O, Baba K, Okada S. Human herpesvirus-6 infection with liver injury in neonatal hepatitis. Lance 1990;335:863.

11 Burd EM, Carrigan DR. Human herpesvirus 6 (HHV-6)associated dysfunction of blood monocytes. Virus Res 1993;29:79-90.

12 Lusso P, Ensoli B, Markham PD, Ablashi DV, Salahuddin Z Tschachler $\mathrm{E}$, et al. Productive dual infection of human CD4+ T lymphocytes by HIV-1 and HHV-6. Nature 1989; 337:370-3

13 Carrigan DR, Knox KK, Tapper MA. Suppression of human immunodeficiency virus type 1 replication by human herpesvirus-6. F Infect Dis 1990;162:844-51.

4 Knox KK, Carrigan DR. HHV-6 and CMV pneumonitis in immunocompromised patients. Lancet 1994;343:1647.

15 Pitalia Ak, Liu-Yin JA, Freemont AJ, Morris DJ, Fitzmaurice RJ. Immunohistochemical detection of human herpesvirus 6 in formalin-fixed, paraffin-embedded lung tissues. Med Virol 1993;41:103-7. 